\title{
KAJIAN METODE EMPIRIS UNTUK MENGHITUNG DEBIT BANJIR SUNGAI NEGARA DI RUAS KECAMATAN SUNGAI PANDAN (ALABIO)
}

\author{
Utami Sylvia Lestari (1) \\ utami.s.lestari@unlam.ac.id
}

(1) Dosen Program Studi Teknik Sipil Fakultas Teknik ULM

\begin{abstract}
Ringkasan
Sungai Negara adalah salah satu sungai di propinsi Kalimantan Selatan yang mempunyai luas daerah aliran sungai (DAS) sebesar $3.921 \mathrm{~km}^{2}$. Di sungai ini sering terjadi banjir yang banyak menyebabkan banyak kerugian. Oleh karena itu diperlukan adanya perhitungan debit banjir untuk mengetahui nilai debit banjir rencana di Sungai Negara.

Tujuan penelitian ini adalah untuk memperoleh penyimpangan nilai debit banjir rencana dari metode empiris dengan data debit terukur sungai sehingga perlu adanya kajian ketelitian untuk mendapatkan debit banjir rencana yang sesuai dengan keadaaan sebenarnya di lapangan. Penelitian ini menggunakan metode studi pustaka dan melakukan analisis terhadap data curah hujan untuk mendapatkan debit banjir pada daerah aliran Sungai Negara dengan Metode Rasional, metode Der Weduwen dan metode Haspers serta melakukan analisis frekuensi terhadap data debit terukur.

Hasil perhitungan data curah hujan menggunakan metode Rasional, metode Der Weduwen dan metode Haspers terhadap nilai analisis frekuensi data debit terukur didapatkan bahwa penyimpangan terkecil terjadi terhadap metode Der Weduwen yaitu sebesar 38.28\% untuk kala ulang 2 tahun, 36.47\% untuk kala ulang 5 tahun, 36.04\% untuk kala ulang 10 tahun, $35.96 \%$ untuk kala ulang 20 tahun, $36.17 \%$ untuk kala ulang 50 tahun dan $36.50 \%$ untuk kala ulang 100 tahun. Oleh karena itu, metode Der Weduwen dapat digunakan sebagai acuan untuk dalam perhitungan debit banjir rencana untuk merencanakan penanggulangan bencana banjir di Sungai Negara.
\end{abstract}

Kata kunci: debit banjir rencana, data curah hujan, data debit terukur, Sungai Negara

\section{PENDAHULUAN}

\section{Latar Belakang}

Sungai Negara adalah salah satu sungai di propinsi Kalimantan Selatan yang mempunyai luas DAS sebesar $3.921 \mathrm{~km} 2$. Di sungai ini sering terjadi banjir yang banyak menyebabkan banyak kerusakan sarana dan prasana umum serta menyebabkan banyak kerugian harta benda. Tidak hanya masyarakat umum yang terkena dampak langsung, pemerintah juga mengalami kerugian yang sangat banyak karena harus melakukan perbaikan sarana dan prasarana umum yang rusak karena terkena banjir. Oleh karena itu debit banjir rencana perlu dihitung untuk mengantisipasi banjir yang akan terjadi dengan cara melakukan perencanaan pengendalian banjir di suatu sungai

Dalam menghitung debit banjir rencana yang berasal dari data curah hujan diperlukan pengontrolan dengan menggunakan data debit terukur dari sungai tersebut. Dalam penggunakan metode empiris dari pengolahan data curah hujan seringkali terdapat penyimpangan hasil dengan data debit banjir rencana hasil data debit terukur sehingga perlu adanya kajian ketelitian agar nantinya dapat diperoleh data debit banjir rencana yang sesuai dengan keadaan sebenarnya di lapangan.

\section{Batasan Masalah}

1. Perhitungan debit banjir rencana dilakukan di ruas Kecamatan Sungai Pandan (Alabio) Kabupaten Hulu Sungai Utara.

2. Analisis hidrologi menggunakan data hujan harian maksimum selama 26 tahun dari 3 stasiun yaitu stasiun Lampihong, stasiun Kambat, dan stasiun Babirik

3. Metode empiris perhitungan debit banjir rencana yang digunakan adalah metode Rasional, Der weduwen dan Haspers

4. Analisis frekuensi data debit mengunakan data debit terukur selama 26 tahun.

5. Kala ulang rencana pada 2, 5, 10, 20, 50 dan 100 tahun.

\section{Tujuan Penelitian}

Tujuan penelitian ini adalah untuk memperoleh penyimpangan nilai debit banjir rencana metode empiris menggunakan 
metode Rasional, metode Der Weduwen dan metode Haspers dengan data debit terukur sungai sehingga perlu adanya kajian ketelitian untuk mendapatkan debit banjir rencana yang sesuai dengan keadaaan sebenarnya

\section{LANDASAN TEORI}

\section{Analisis Curah Hujan Rerata Daerah}

Curah hujan yang diperlukan untuk menghitung debit banjir adalah data curah hujan harian maksimum di seluruh daerah yang bersangkutan, bukan curah hujan pada suatu titik tertentu. Curah hujan ini disebut curah hujan wilayah/daerah dan dinyatakan dalam $\mathrm{mm}$.

Salah satu cara pendekatan untuk menentukan curah hujan harian maksimum rata-rata pada suatu daerah aliran sungai adalah dengan menggunakan metode Thiessen (Suyono Sosrodarsono, 2006) dengan persamaan sebagai berikut

$$
P=\frac{A_{1} P_{1}+A_{2} P_{2}+\ldots+A_{n} P_{n}}{A_{1}+A_{2}+\ldots+A_{n}}
$$

dengan :

$\mathrm{P} \quad=$ tinggi hujan rata-rata $(\mathrm{mm})$

$P_{1} . . P_{n}=$ tinggi hujan di setiap titik pengamatan $(\mathrm{mm})$

$A_{1} . . A_{n}=$ luas yang dibatasi garis polygon $\left(\mathrm{km}^{2}\right)$

\section{Analisis Distribusi Frekuensi Curah Hujan Maksimum}

Dalam melakukan analisis distribusi frekuensi data curah hujan dilakukan dengan 4 metode yaitu metode distribusi normal, metode distribusi log normal, metode distribusi gumbel dan metode distribusi log pearson type III.

\section{Distribusi Normal}

Persamaan metode distribusi Normal (Sri Harto $\mathrm{Br}, 1993)$ adalah:

$$
X_{T r}=\bar{X}+K_{T r} \cdot S_{X}
$$

dengan:

$\mathrm{X}_{\mathrm{Tr}}$ = besarnya curah hujan rencana untuk periode ulang $T$ tahun.

$$
\begin{aligned}
\bar{X} & =\text { harga rata-rata dari data } \\
& =\frac{\sum_{1}^{n} X_{i}}{n}
\end{aligned}
$$

$$
\begin{aligned}
\text { Sx } & =\text { simpangan baku } \\
& =\sqrt{\frac{\sum(X i-\bar{X})^{2}}{n-1}} \\
\mathrm{~K}_{\mathrm{Tr}} & =\text { variabel reduksi Gauss }
\end{aligned}
$$

\section{Distribusi Log Normal}

Persamaan meode distribusi Log Normal (Sri Harto $\mathrm{Br}$, 1993) adalah:

$$
\log X_{T r}=\overline{\log X}+K_{T r} \cdot S_{\log X}
$$

dengan :

$\log X_{T r}$ = besarnya curah hujan rencana untuk periode ulang $T$ tahun.

$\overline{\log X}=$ harga rata-rata dari data

$$
\begin{aligned}
& =\frac{\sum_{1}^{n} \log \left(X_{i}\right)}{n} \\
S_{\log X} & =\text { simpangan baku } \\
& =\sqrt{\frac{\sum(\log X-\overline{\log X})^{2}}{n-1}} \\
\mathrm{~K}_{\mathrm{Tr}} & =\text { variabel reduksi Gauss }
\end{aligned}
$$

\section{Distribusi Gumbel}

Persamaan metode Gumbel (Sri Harto $\mathrm{Br}, 1993)$ adalah:

$$
X_{T r}=\bar{X}+K \cdot S_{X}
$$

dengan:

$\mathrm{X}_{\mathrm{Tr}}=$ besarnya curah hujan rencana untu periode ulang $T$ tahun.

$\bar{X}=$ harga rata-rata dari data

$$
=\frac{\sum_{1}^{n} X_{i}}{n}
$$

$S_{x}=$ simpangan baku

$$
=\sqrt{\frac{\sum(X i-\bar{X})^{2}}{n-1}}
$$

$\mathrm{K}=$ faktor frekuensi yang merupakan fungsi dari periode ulang (return period) dan tipe frekuensi

Untuk menghitung faktor frekuensi Gumbel mengambil harga :

$$
\mathrm{K}=\frac{y_{t}-y_{n}}{S_{n}}
$$


dengan:

$y_{t}=$ reduksi sebagai fungsi dari probabilitas

$\mathrm{y}_{\mathrm{n}}$ dan $\mathrm{Sn}$ = besaran yang merupakan fungsi dari jumlah pengamatan

\section{Distribusi Log Pearson Type III}

Persamaan metode Log Pearson Type III (Sri Harto $\mathrm{Br}, 1993$ ) adalah:

$\log \mathrm{X}_{\mathrm{Tr}}=\overline{\log X}+\mathrm{K}_{\mathrm{Tr}} \cdot\left(\mathrm{S}_{\log \mathrm{X}}\right)$

dengan:

$\log X_{T}=$ besarnya curah hujan rencana untuk periode ulang $T$ tahun

$\overline{\log X}=$ harga rata-rata dari data

$$
=\frac{\sum_{i=1}^{n} \log X_{i}}{n}
$$

$S_{\log X} \quad=$ simpangan baku

$$
=\sqrt{\frac{\sum_{i=1}^{n}\left(\log X_{i}-\overline{\log X}\right)^{2}}{n-1}}
$$

$\mathrm{K}_{\mathrm{tr}}=$ koefisien frekuensi, didapat berdasarkan hubungan nilai $\mathrm{Cs}$ dengan periode ulang $T$

Cs

$$
=\frac{n \cdot \sum_{i=1}^{n}\left(\log X_{i}-\overline{\log X}\right)^{3}}{(n-1)(n-2) \cdot\left(S_{\log X}\right)^{3}}
$$

\section{Pengujian Kesesuaian Distribusi Frekuensi}

Uji kesesuaian ini dimaksud untuk mengetahui kebenaran suatu hipotesa distribusi frekuensi. Dengan pemeriksaan ini akan diperoleh :

1. Kebenaran antara hasil pengamatan dengan metode distribusi yang diharapkan atau yang diperoleh secara teoritis.

2. Kebenaran hipotesa diterima atau ditolak untuk digunakan pada perhitungan selanjutnya.

Ada 2 cara untuk mengadakan uji kesesuaian distribusi yaitu Chi Kuadrat dan uji.

\section{Uji Chi - Kuadrat}

Uji Chi-Kuadrat (uji data vertikal) adalah ukuran perbedaan yang didapat antara frekuensi yang diamati dengan yang diharapkan. Uji ini digunakan untuk menguji simpangan tegak lurus yang ditentukan dengan rumus Shahin (Soewarno, 1995):

$$
\left(x^{2}\right)_{h i t}=\sum_{i=1}^{k} \frac{(E F-O F)^{2}}{E F}, \quad E F=\frac{n}{k}
$$

Dengan :

$\mathrm{X}^{2}$ hit $=$ Uji statistik

$\mathrm{OF}=$ Nilai yang diamati (Observed frequency)

$\mathrm{EF}=$ Nilai yang diharapkan (Expected frequency)

Uji Chi - Kuadrat merupakan uji simpangan vertikal dengan langkah-langkah sebagai berikut:

a. Tentukan jumlah kelas disribusi $(\mathrm{K})$

b. $K=1+3,22 \log n, n=$ banyaknya data

c. Cari nilai Chi kuadrat hitung $\left(X^{2}\right)_{c r}$

d. Besarnya nilai $\left(X^{2}\right)_{\text {cr }}$ dapat diperoleh berdasarkan taraf signifikan ( $\alpha$ ) dan derajat bebasnya (DK). Dengan memasukkan harga $\mathrm{K}$ dan sebaran Chi Kuadrat dapat diperoleh harga DK.

e. $D K=K-(P-1)$

f. Kemudian nilai $\left(\mathrm{X}^{2}\right)_{\text {cr }}$ dibandingkan dengan nilai chi kuadrat kritis $\left(\mathrm{X}^{2}\right)_{\text {cr. }}$

g. Jika Nilai $\left(X^{2}\right)_{c r}>\left(X^{2}\right)$ hitung, berarti sebaran vertikal dapat diterima

\section{Uji Smirnov Kolmogorov}

Uji Smirnov - Kolmogorov (uji data horizontal) digunakan untuk menguji simpangan secara mendatar (Soewarno, 1995). Untuk melakukan pengujian data terhadap simpangan horizontal, menggunakan rumus :

$$
\Delta_{m a k s}=\left|P_{E}(x)-P_{t}(x)\right|
$$

Dimana :

$\Delta$ maks = Selisih data probabilitas teoritis dan empiris

$\mathrm{P}_{\mathrm{t}}(\mathrm{X})=$ Posisi data $\mathrm{X}$ menurut sebaran teoritis

$\mathrm{P}_{\mathrm{e}}(\mathrm{X})=$ Posisi data $\mathrm{X}$ menurut sebaran empiris

Dari hasil perhitungan diperoleh perbedaan yang maksimum antara distribusi teoritis dan distribusi empiris yang disebut dengan $\Delta$ maksimum. Kemudian Nilai $\Delta_{\text {maksimum }}$ hasil perhitungan dibandingkan dengan $\Delta_{c r}$ yang diperoleh dari tabel untuk suatu derajat yang tertentu yang mana pada studi ini digunakan nilai kritis (significant level) $\alpha=5 \%$. Apabila $\Delta_{\mathrm{cr}}>\Delta_{\text {maksimum maka hipotesa dapat diterima }}$

\section{Analisis Debit Banjir Rencana}




\section{Analisis Debit Banjir Rencana Metode Rasional}

Metode yang paling sering digunakan untuk mengestimasi debit di suatu daerah aliran sungai dimana tidak ada data pengamatan debitnya adalah Metode Rasional Jepang. Dalam hal ini besarnya debit tersebut merupakan fungsi dari luas DAS, intensitas hujan, keadaan pemukaan tanah yang dinyatakan dalam koefisien limpasan dan kemiringan sungai (Joesron Loebis, 1992). Debit banjir dirumuskan secara generik sebagai berikut:

$$
\mathbf{Q}=\text { C. I . A }
$$

Untuk kepentingan kepraktisan dalam penentuan satuan, maka :

$$
Q p=0.278 . C . I . A
$$

Dimana :

$\mathrm{Qp}=$ debit puncak $\left(\mathrm{m}^{3} / \mathrm{det}\right)$

$\mathrm{C}=$ koefisien limpasan

I = Intensitas hujan dengan durasi sama dengan waktu konsentrasi banjir ( $\mathrm{mm} / \mathrm{jam})$

$$
\mathrm{A}=\text { luas daerah aliran sungai }\left(\mathrm{km}^{2}\right)
$$

\section{Koefisien Aliran Permukaan ( C )}

Merupakan suatu harga rasio antara aliran permukaan dengan intensitas hujan untuk suatu daerah tangkapan tertentu. Pada kenyataannya, koefisien ini dihitung dari besarnya hambatan atau kehilangan dari curah hujan sehingga menjadi aliran permukaan. Besarnya kehilangan ini tergantung pada kondisi vegetasi, infiltrasi, kolam-kolam permukaan dan evapotranspirasi. Harga koefisien limpasan (C) dapat dilihat pada (tabel 1).

Tabel 1. Koefisien Limpasan (C )

\begin{tabular}{|l|c|}
\hline \multicolumn{1}{|c|}{ Keadaan Daerah Pengaliran } & Koefisien \\
\hline $\begin{array}{l}\text { Daerah pegunungan yang } \\
\text { curam }\end{array}$ & $0,75-0,90$ \\
\hline Daerah pegunungan tersier & $0,70-0,80$ \\
\hline $\begin{array}{l}\text { Sungai dengan tanah dan hutan } \\
\text { di bagian atas dan bawahnya }\end{array}$ & $0,50-0,75$ \\
\hline Tanah dasar yang ditanami & $0,45-0,60$ \\
\hline Sawah waktu diairi & $0,70-0,80$ \\
\hline Sungai bergunung & $0,75-0,85$ \\
\hline Sungai dataran & $0,45-0,75$ \\
\hline
\end{tabular}

Sumber : Soewarno, 1991

\section{Waktu Konsentrasi (Tc)}

Yang dimaksud dengan waktu konsentrasi ialah waktu perjalanan yang diperlukan oleh air dari tempat yang paling jauh (hulu DAS) sampai ke titik pengamatan aliran air (Outlet) (Imam Subarkah, 1978).

$$
T c=0.0195 L^{0.77} S^{-0.385}
$$

Dimana:
Tc $=$ Waktu konsentrasi $(\mathrm{m})$

$\mathrm{L}=$ Panjang sungai/lereng $(\mathrm{m})$

$\mathrm{S}=$ Kemirimgan lereng $(\mathrm{m} / \mathrm{m}$

\section{Intensitas Hujan ( I )}

Yang dimaksud dengan Intensitas Hujan adalah tinggi curah hujan dalam periode tertentu yang dinyatakan dalam $\mathrm{mm} / \mathrm{jam}$. Untuk menentukan besar intensitas hujan dipergunakan rumus Mononobe (Joesron Loebis, 1992) yaitu:

$$
\begin{aligned}
I & =\frac{R_{24}}{24}\left(\frac{24}{t}\right)^{2 / 3} \\
\mathrm{I} & =\text { Intensitas hujan (mm/jam) } \\
\mathrm{R}_{24} & =\text { Curah hujan harian maksimum (mm) } \\
\mathrm{T} & =\text { Waktu curah hujan (jam) }
\end{aligned}
$$

\section{Analisis Debit Banjir Rencana Metode Der Weduwen}

Untuk menghitung debit rancangan dengan metode Der Weduwen didasarkan pada rumus berikut ini (Joesron Loebis, 1992):

$$
\begin{aligned}
Q n & =\alpha \beta q_{n} A \\
\alpha & =1-\frac{4.1}{\beta q_{n}+7} \\
\beta & =\frac{120+\frac{t+1}{t+9} A}{120+A} \\
q_{n} & =\frac{R_{n}}{240} \cdot \frac{67.65}{t+1.45} \\
\mathrm{t} \quad & =0.25 \mathrm{LQ}^{-0.125} \mathrm{I}^{-0.25}
\end{aligned}
$$

Dimana :

Qn $=$ debit rancangan $\left(\mathrm{m}^{3} / \mathrm{dt}\right)$ dengan kala ulang $\mathrm{n}$ tahun

$\mathrm{Rn}=$ curah hujan rancangan $(\mathrm{mm} / \mathrm{hari})$ periode ulang $\mathrm{n}$ tahun

$\alpha=$ koefisien limpasan air hujan

$\beta=$ koefisien pengurangan luas untuk curah hujan di daerah aliran sungai

$\mathrm{qn}=$ luasan curah hujan $\left(\mathrm{m}^{3} / \mathrm{dt} \cdot \mathrm{km}^{2}\right)$

$A=$ luas DAS

$\mathrm{t}=$ lamanya hujan, jam

$\mathrm{L}=$ panjang sungai, $\mathrm{km}$

$\mathrm{I}=$ kemiringan sungai

\section{Analisis Debit Banjir Rencana Metode Haspers}

Metode yang digunakan untuk mengestimasi debit rancangan adalah Metode Hasper. Persamaan umum yang digunakan adalah (Joesron Loebis, 1992):

$\mathrm{Qi}=\alpha \times \beta \times \mathrm{A} \times \mathrm{qt}$

dengan : 


$$
\begin{aligned}
& \alpha=\frac{1+0,012 \cdot \mathrm{A}^{0,7}}{1+0,075 \cdot \mathrm{A}^{0,7}} \\
& \mathrm{tc}=0,1 \cdot \mathrm{L}^{0,8} \cdot \mathrm{j}^{-0,3} \\
& \frac{1}{\beta}=1+\frac{\mathrm{t}+\left(3,7 \cdot 10^{-0,4 \mathrm{t}}\right)}{\mathrm{t}^{2}+15} \cdot \frac{\mathrm{A}^{3 / 4}}{12} \\
& q t=\frac{R t}{3,6 \cdot t} \\
& \text { Untuk } \mathrm{t}<2 \text { jam } \quad t \times R_{24} \\
& R t=\frac{t+1-0,008\left(260-R_{24}\right)(2-t)^{2}}{t}
\end{aligned}
$$

Untuk 2 jam $<\mathrm{t} \leq 19$ jam

$$
R t=\frac{t \times R_{24}}{t+1}
$$

Untuk 19 jam $<\mathrm{t} \leq 30$ hari

$R t=0,707 \times R_{24}(t+1) \times 0,5$

dimana :

$$
\begin{aligned}
\alpha & =\text { Koefisien pengaliran } \\
\beta & =\text { Koefisien reduksi } \\
\mathrm{t} & =\text { Waktu konsentrasi (jam) } \\
\mathrm{A} & =\text { Luas DAS }\left(\mathrm{km}^{2}\right) \\
\mathrm{L} & =\text { Panjang sungai }(\mathrm{km}) \\
\mathrm{i} & =\text { kemiringan sungai rerata } \\
\mathrm{R}_{24} & =\text { Curah hujan rancangan }(\mathrm{mm}) \\
\mathrm{Rt} & =\text { Intensitas hujan } \\
\mathrm{Qt} & =\text { Hujan maksimum }\left(\mathrm{m}^{3} / \mathrm{km}^{3} / \mathrm{det}\right)
\end{aligned}
$$

\section{Analisis Frekuensi data debit terukur}

Tujuan dari analisis frekuensi data hidrologi adalah mencari hubungan antara besarnya kejadian ekstrim terhadap frekuensi kejadian dengan menggunakan ditribusi probabilitas. Analisis frekuensi dapat diterapkan untuk data debit sungai atau data hujan. Data yang digunakan adalah data debit atau hujan maksimum tahunan, yaitu data terbesar yang terjadi selama satu tahun, yang terukur selama beberapa tahun (Triatmodjo, 2008).

\section{METODOLOGI PENELITIAN}

Langkah-langkah yang ditempuh dalam analisis ini adalah studi pustaka/literatur, survei lapangan, pengumpulan data sekunder, dan analisis data. Tahapan analisis data yang dilakukakan yaitu data curah hujan harian maksimum selama 26 tahun dari 3 stasiun yaitu stasiun Lampihong, Stasiun Kambat dan Stasiun Babirik kemudian dijadikan curah hujan rerata maksimum daerah dengan menggunakan Metode Thiessen. Data tersebut seterusnya dianalisis distribusi frekuensi data curah hujannya dengan menggunakan distribusi normal, distribusi log normal, distribusi gumbel dan distribusi log person type III. Kemudian dilakukan uji kesesuaian distribusi frekuensi dengan Uji Chi-Kuadrat dan Uji Smirnov Kolmogorov. Kemudian dilanjutkan dengan melakukan analisis debit rencana dari data curah hujan dengan metode Rasional, metode Der Weduwen dan metode Haspers.

Dari data debit terukur selam 26 tahun dilakukan analisis distribusi frekuensi dengan menggunakan 4 metode yaitu distribusi normal, metode distribusi log normal, metode distribusi gumbel dan metode distribusi log pearson type III. Dari hasil analisis distribusi frekuensi kemudian dilakukan uji kesesuain distribusi dengan menggunakan uji ChiKuadrat dan uji Smirnov Kolmogorov.

Tahapan analisis selanjutnya adalah membandingkan nilai banjir rencana dari data curah hujan dengan menggunakan metode Rasional, metode Der Weduwen dan motode Haspers dengan nilai banjir rencana dari data debit terukur sehingga diperoleh nilai penyimpangan dari analisis tersebut. Debit banjir rencana tersebut nantinya dapat digunakan sebagai patokan untuk perencanaan bangunan air sebagai upaya penanggulangan bencana banjir yang sering terjadi.

\section{HASIL DAN PEMBAHASAN}

\section{Analisis Curah Hujan Rencana}

Data curah hujan harian maksimum yang digunakan dalam analisa ini bersumber dari BMKG Stasiun Klimatotogi Banjarbaru dengan periode pencatatan $1989 \mathrm{~s} / \mathrm{d}$ 2014. Stasiun pengamatan yang digunakan adalah stasiun yang berada di dalam lokasi penelitian. Stasiun yang digunakan yaitu Stasiun Lampihong, Stasiun Kambat, Stasiun Babirik.

Data hujan yang diperoleh dari alat penakar hujan yang terjadi pada satu tempat atau titik saja (point rainfall). Mengingat hujan yang sangat bervariasi terhadap tempat, maka untuk kawasan yang luas, satu alat penakar hujan belum dapat menggambarkan hujan wilayah tersebut. Dalam hal ini diperlukan hujan kawasan yang diperoleh dari harga ratarata curah hujan beberapa stasiun penakar hujan yang ada di dalam dan atau di sekitar kawasan tersebut.

Di sekitar lokasi studi terdapat tiga stasiun penakar hujan yang dianggap relevan untuk mewakili pengamatan hujan di daerah studi (Stasiun Hujan Kambat, Stasiun Hujan Lampihong dan Statiun Hujan Babirik). Dalam studi ini hujan rerata daerah dicari dengan 
menggunakan Metode Thiessen. Metode ini hasilnya akan lebih teliti untuk daerah-daerah dimana distribusi dari pengamat hujan tidak tersebar merata.

Data curah hujan yang digunakan dalam studi ini adalah data curah hujan harian maksimum dari 3 (tiga) buah stasiun pencatat hujan yang bisa mewakili lokasi studi, dimana lamanya periode pencatatan data yang tersedia adalah selama 26 tahun (tahun 1989 sampai dengan tahun 2014). Data curah hujan efektif tahunan dapat dilihat pada (tabel 2)

Tabel 2. Curah Hujan Efektif Tahunan pada DAS Negara

\begin{tabular}{|c|c|c|c|c|}
\hline \multirow{2}{*}{ Tahun } & Sta.Lampihong & Sta. Babirik & Sta. Kambat & \multirow{2}{*}{$\begin{array}{l}\text { CH Rerata Daerah } \\
(\mathrm{mm})\end{array}$} \\
\hline & 0.23770 & 0.58607 & 0.17623 & \\
\hline 1989 & 25 & 125 & 50 & 88.01 \\
\hline 1990 & 197 & 83 & 160 & 123.67 \\
\hline 1991 & 217 & 160 & 98 & 162.62 \\
\hline 1992 & 115 & 74 & 210 & 107.71 \\
\hline 1993 & 92 & 95 & 110 & 96.93 \\
\hline 1994 & 60 & 91 & 302 & 120.83 \\
\hline 1995 & 80 & 122 & 79 & 104.44 \\
\hline 1996 & 100 & 64 & 75 & 74.50 \\
\hline 1997 & 75 & 58 & 90 & 67.68 \\
\hline 1998 & 16 & 71 & 88 & 60.92 \\
\hline 1999 & 100 & 97 & 105 & 99.19 \\
\hline 2000 & 110 & 72 & 103 & 86.50 \\
\hline 2001 & 102 & 108 & 149 & 113.68 \\
\hline 2002 & 97 & 82 & 112 & 90.85 \\
\hline 2003 & 197 & 115 & 105 & 132.73 \\
\hline 2004 & 137 & 103 & 72 & 105.62 \\
\hline 2005 & 115 & 72 & 58 & 79.75 \\
\hline 2006 & 111 & 72 & 90 & 84.44 \\
\hline 2007 & 60 & 91 & 109 & 86.80 \\
\hline 2008 & 30 & 81 & 79 & 68.52 \\
\hline 2009 & 100 & 75 & 125 & 89.75 \\
\hline 2010 & 85 & 158 & 117 & 133.42 \\
\hline 2011 & 16 & 86 & 105 & 72.78 \\
\hline 2012 & 100 & 73 & 76 & 79.95 \\
\hline 2013 & 110 & 128 & 184 & 133.59 \\
\hline 2014 & 102 & 174 & 132 & 149.37 \\
\hline
\end{tabular}

Sumber: hasil perhitungan

\section{Analisis Distribusi Frekuensi Data Curah Hujan}

Ada 4 metode untuk melakukan analisis distribusi frekuensi data curah hujan yaitu Distribusi Normal, Distribusi Log Normal, Distribusi Gumbel dan Distribusi Log Pearson Type III.

\section{Distribusi Normal}

Hasil analisis distribusi frekuensi data curah hujan dengan menggunakan Distribusi Normal dapat dilihat pada tabel 3.

Tabel 3. Curah Hujan Rencana Distribusi

\begin{tabular}{|c|c|c|}
\hline No. & $\begin{array}{c}\text { Periode Ulang } \\
\text { (tahun) }\end{array}$ & $\begin{array}{c}\text { Curah Hujan } \\
(\mathrm{mm})\end{array}$ \\
\hline 1 & 2 & 100.549 \\
\hline 2 & 5 & 122.878 \\
\hline 3 & 10 & 134.575 \\
\hline 4 & 20 & 144.145 \\
\hline 5 & 50 & 155.043 \\
\hline 6 & 100 & 162.487 \\
\hline
\end{tabular}

Sumber : Hasil Perhitungan

Distribusi Log Normal
Hasil analisis distribusi frekuensi data curah hujan dengan menggunakan Distribusi Log Normal dapat dilihat pada tabel 4.

Tabel 4. Curah Hujan Rencana Distribusi Log Normal

\begin{tabular}{|c|c|c|}
\hline No. & $\begin{array}{c}\text { Periode Ulang } \\
\text { (tahun) }\end{array}$ & $\begin{array}{c}\text { Curah Hujan } \\
(\mathrm{mm})\end{array}$ \\
\hline 1 & 2 & 97.336 \\
\hline 2 & 5 & 120.946 \\
\hline 3 & 10 & 135.518 \\
\hline 4 & 20 & 148.737 \\
\hline 5 & 50 & 165.370 \\
\hline 6 & 100 & 177.785 \\
\hline
\end{tabular}

Sumber : Hasil Perhitungan

\section{Distribusi Gumbel}

Hasil analisis distribusi frekuensi data curah hujan dengan menggunakan Distribusi Gumbel dapat dilihat pada tabel 5.

Tabel 5. Curah Hujan Rencana Distribusi Gumbel 


\begin{tabular}{|c|c|c|}
\hline No. & $\begin{array}{c}\text { Periode Ulang } \\
\text { (tahun) }\end{array}$ & $\begin{array}{c}\text { Curah Hujan } \\
(\mathrm{mm})\end{array}$ \\
\hline 1 & 2 & 96.87 \\
\hline 2 & 5 & 122.06 \\
\hline 3 & 10 & 138.74 \\
\hline 4 & 20 & 154.74 \\
\hline 5 & 50 & 175.44 \\
\hline 6 & 100 & 190.96 \\
\hline
\end{tabular}

Sumber : Hasil Perhitungan

\section{Distribusi Log Pearson Type III}

Hasil analisis distribusi frekuensi data curah hujan dengan menggunakan Distribusi Log Pearson Type III dapat dilihat pada (tabel $6)$.

Tabel 6. Curah Hujan Rencana Distribusi Log Pearson Type III

\begin{tabular}{|c|c|c|}
\hline No. & $\begin{array}{c}\text { Periode Ulang } \\
\text { (tahun) }\end{array}$ & $\begin{array}{c}\text { Curah Hujan } \\
(\mathrm{mm})\end{array}$ \\
\hline 1 & 2 & 97.02 \\
\hline 2 & 5 & 120.87 \\
\hline 3 & 10 & 135.85 \\
\hline 4 & 20 & 147.74 \\
\hline 5 & 50 & 167.21 \\
\hline 6 & 100 & 180.11 \\
\hline
\end{tabular}

Sumber : Hasil Perhitungan
Pengujian Kesesuaian Distribusi Frekuensi

Uji kesesuaian ini dimaksudkan untuk mengetahui kebenaran suatu hipotesa distribusi frekuensi. Ada 2 cara untuk melakukan uji kesesuaian distribusi yaitu Uji Chi-Kuadrat dan Uji Smirnov-Kolmogorov.

\section{Pengujian Kesesuaian Distribusi Frekuensi menggunakan Uji Chi-Kuadrat}

Hasil Uji Chi-Kuadrat terhadap distribusi Normal, distribusi Log Normal, distribusi Gumbel dan distribusi Log Pearson Type III dapat dilihat pada tabel 7

Dari tabel 7 dapat dilihat bahwa dari hasil uji Chi-Kuadrat maka distribusi frekuensi yang memenuhi syarat adalah Distribusi Normal, Distribusi Log Normal dan Distribusi Gumbel

\section{Pengujian Kesesuaian Distribusi Frekuensi menggunakan Uji Smirnov-Kolmogorov}

Hasil Uji Smirnov-Kolmogorov terhadap Distribusi Normal, Distribusi Log Normal, Distribusi Gumbel dan Distribusi Log Pearson Type III dapat dilihat pada tabel 8.

Tabel 7. Hasil Uji Chi-Kuadrat

\begin{tabular}{|c|c|c|c|c|c|}
\hline \multirow{2}{*}{ No. } & \multirow{2}{*}{ Distribusi } & \multirow{2}{*}{ Chi $^{2}$ Hitung } & \multicolumn{2}{|c|}{$\mathrm{Chi}^{2}$ tahel } & \multirow{2}{*}{ Kesimpulan } \\
\cline { 4 - 5 } & Normal & 2,615 & 7,815 & 11,345 & Diterima \\
\hline 1 & Log Normal & 0,769 & 7,815 & 11,345 & Diterima \\
\hline 3 & Gumbel & 0,769 & 7,815 & 11,345 & Diterima \\
\hline 4 & Log Pearson III & 18,308 & 7,815 & 11,345 & Ditolak \\
\hline
\end{tabular}

Sumber : Hasil Perhitungan

Tabel 8. Hasil Uji Smirnov-Kolmogorov

\begin{tabular}{|c|c|c|c|c|c|}
\hline \multirow{2}{*}{ No. } & \multirow{2}{*}{ Distribusi } & \multirow{2}{*}{ D maks } & \multicolumn{2}{|c|}{ Do tabel } & \multirow{2}{*}{ Kesimpulan } \\
\cline { 4 - 5 } & & $5 \%$ & $1 \%$ & \\
\hline 1 & Normal & 0,175 & 0,264 & 0,314 & Diterima \\
\hline 2 & Log Normal & 0,426 & 0,264 & 0,314 & Ditolak \\
\hline 3 & Gumbel & 0,179 & 0,264 & 0,314 & Diterima \\
\hline 4 & Log Pearson III & 0,942 & 0,264 & 0,314 & Ditolak \\
\hline
\end{tabular}

Sumber : Hasil Perhitungan

Dari tabel 8 dapat dilihat bahwa dari hasil Uji Smirnov-Kolmogorov maka distribusi frekuensi yang memenuhi syarat adalah Distribusi Normal dan Distribusi Gumbel.

Distribusi Curah Hujan Maksimum Terpilih Rekapitulasi Pengujian Distribusi Curah Hujan Efektif dapat dilihat pada tabel 9. Berdasarkan pengujian distibusi curah hujan baik Uji ChiKuadrat maupun Uji Smirnov-Kolmogorov maka distribusi yang dapat memenuhi kedua uji tersebut adalah Distribusi Normal dan
Distribusi Gumbel. Sehingga curah hujan rencana yang selanjutnya digunakan untuk analisis debit rencana adalah curah hujan rencana Distribusi Gumbel

\section{Analisis Debit Banjir Rencana Data Curah Hujan}

Dari hasil perhitungan curah hujan rencana dengan berbagai kala ulang, maka diperoleh debit rencana dengan metode empiri dengan untuk kala ulang 2 tahun, 5 tahun, 10 tahun, 20 tahun, 50 tahun dan 100 tahun. 


\begin{tabular}{|l|l|l|l|l|}
\hline \multirow{2}{*}{$\begin{array}{l}\text { Periode } \\
\text { Ulang }\end{array}$} & Dist. Normal & Dist. Log Normal & Dist. Gumbel & $\begin{array}{l}\text { Dist. Log Pearson } \\
\text { III }\end{array}$ \\
\cline { 2 - 5 } & Analitis & Analitis & Analitis *) & Analitis \\
\hline T (tahun) & $(\mathrm{mm})$ & $(\mathrm{mm})$ & $(\mathrm{mm})$ & $(\mathrm{mm})$ \\
\hline 2 & 100.55 & 97.34 & 96.87 & 97.02 \\
\hline 5 & 122.88 & 120.95 & 122.06 & 120.87 \\
\hline 10 & 134.57 & 135.52 & 138.74 & 135.85 \\
\hline 20 & 144.14 & 148.74 & 154.74 & 147.74 \\
\hline 50 & 155.04 & 165.37 & 175.44 & 167.21 \\
\hline 100 & 162.49 & 177.78 & 190.96 & 180.11 \\
\hline
\end{tabular}

Keterangan : *) Distribusi yang digunakan

Sumber : Hasil Perhitungan

Tabel 10. Hasil Perhitungan Debit Banjir Rencana dengan Metode Rasional

\begin{tabular}{ccccccc}
\hline \multirow{2}{*}{ Parameter } & \multicolumn{7}{c}{ Kala Ulang T (Tahun) } \\
\cline { 2 - 7 } & 2 & 5 & 10 & 20 & 50 & 100 \\
\hline Tc (jam) & 23.731 & 23.731 & 23.731 & 23.731 & 23.731 & 23.731 \\
I (m/jam) & 0.3099 & 0.3904 & 0.4438 & 0.4950 & 0.5612 & 0.6108 \\
Q & & & & & & \\
$\left(\mathrm{m}^{3} /\right.$ det $)$ & 214.31 & 270.04 & 306.94 & 342.34 & 388.134 & 422.47 \\
\hline
\end{tabular}

Sumber : Hasil Perhitungan

Tabel 11. Hasil Perhitungan Debit Banjir Rencana dengan Metode Der Weduwen

\begin{tabular}{cccc}
\hline Kala Ulang & $\begin{array}{c}\text { Hujan Rencana } \\
(\mathrm{RT})\end{array}$ & $\begin{array}{c}\mathrm{t} \\
\text { (waktu konsentasi) }\end{array}$ & $\begin{array}{c}\text { Debit } \\
\left(\mathrm{m}^{3} / \mathrm{det}\right)\end{array}$ \\
\hline 2 & 96.87 & 98.95 & 579.43 \\
5 & 122.06 & 96.13 & 740.97 \\
10 & 138.74 & 94.32 & 850.24 \\
20 & 154.74 & 92.94 & 956.74 \\
50 & 175.44 & 91.36 & 1096.92 \\
100 & 190.96 & 90.40 & 1203.73 \\
\hline
\end{tabular}

Sumber : Hasil Perhitungan

Tabel 12. Hasil Perhitungan Debit Banjir Rencana dengan Metode Hasper

\begin{tabular}{ccccccc}
\hline $\begin{array}{c}\text { Kala } \\
\text { Ulang } \\
\text { (tahun) }\end{array}$ & $\mathrm{R}_{24}$ & $\mathrm{r}$ & $\alpha$ & $\beta$ & $\mathrm{Rt}$ & $\begin{array}{c}\mathrm{Q} \\
\left(\mathrm{m}^{3} / \mathrm{det}\right)\end{array}$ \\
\hline 2 & 96.87 & 2.888 & 0.193 & 0,637 & 376.509 & 1026.53 \\
5 & 122.06 & 4.038 & 0.193 & 0,637 & 526.445 & 1435.32 \\
10 & 138.74 & 5.188 & 0.193 & 0,637 & 598.377 & 1631.43 \\
25 & 154.74 & 6.338 & 0.193 & 0,637 & 667.375 & 1819.55 \\
50 & 175.44 & 7.488 & 0.193 & 0,637 & 756.686 & 2063.05 \\
100 & 190.96 & 8.638 & 0.193 & 0,637 & 823.612 & 2245.52 \\
\hline
\end{tabular}

Sumber : Hasil Perhitungan

\section{Analisis Frekuensi Data Debit}


Data debit maksimum Sungai Negara adalah sebagamana (tabel 13). Dari hasil analisis frekuensi data debit terukur dengan menggunakan distribusi normal,distribusi log normal, distribusi gumbel dan distribusi log person type III serta pengujian kesesuaian distribusi dengan Uji Chi-Kuadrat dan Uji Smirnov Kolmogorov maka didapat debit banjir rencana sebagaimana (tabel 14)

Tabel 13. Data debit terukur Sungai Negara

\begin{tabular}{|c|c|c|}
\hline No. & Tahun & $\begin{array}{c}\text { Debit Maksimum Sungai Negara } \\
\left(\mathrm{m}^{3} / \text { det }\right)\end{array}$ \\
\hline 1 & 1990 & 669.956 \\
2 & 1991 & 536.087 \\
3 & 1992 & 489.356 \\
4 & 1993 & 479.139 \\
5 & 1994 & 464.393 \\
6 & 1995 & 594.947 \\
7 & 1996 & 525.799 \\
8 & 1997 & 479.139 \\
9 & 1998 & 380.474 \\
10 & 1999 & 263.173 \\
11 & 2000 & 490.077 \\
12 & 2001 & 637.658 \\
13 & 2002 & 365.511 \\
14 & 2003 & 567.512 \\
15 & 2004 & 223.452 \\
16 & 2005 & 301.694 \\
17 & 2006 & 540.447 \\
18 & 2007 & 223.452 \\
19 & 2008 & 389.535 \\
20 & 2009 & 617.301 \\
21 & 2010 & 269.456 \\
22 & 2011 & 293.333 \\
23 & 2012 & 296.100 \\
24 & 2013 & 442.421 \\
25 & 2014 & 420.294 \\
26 & 2015 & 404.255 \\
\hline
\end{tabular}

Tabel 14. Debit banjir rencana berdasarkan data debit terukur

\begin{tabular}{|c|c|}
\hline Periode Ulang & Debit Banjir \\
$\mathrm{T} \quad$ (tahun) & $\left(\mathrm{m}^{3} /\right.$ det $)$ \\
\hline 2 & 419.02 \\
5 & 542.94 \\
10 & 624.98 \\
20 & 703.68 \\
50 & 805.55 \\
100 & 881.89 \\
\hline
\end{tabular}

Sumber : Hasil Perhitungan

Analisis Penyimpangan (\%) Debit Banjir Data Curah Hujan terhadap Debit Banjir Data Debit
Berdasarkan perhitungan debit banjir rencana data curah hujan Sungai Negara dengan menggunakan metode Rasional, 
metode Der Weduwen dan metode Haspers serta perhitungan debit banjir rencana berdasarkan data debit terukur maka diperoleh penyimpangan debit banjir rencana yang dapat dilihat pada table 15, tabel 16 dan tabel 17 berikut ini.

Tabel 15. Penyimpangan (\%) debit banjir rencana metode Rasional terhadap debit banjir rencana data debit

\begin{tabular}{|c|c|c|c|c|c|c|}
\hline \multirow{3}{*}{$\begin{array}{l}\text { Kala } \\
\text { Ulang }\end{array}$} & \multirow{2}{*}{$\begin{array}{c}Q \\
\text { Terukur } \\
\text { (m3/det) }\end{array}$} & \multirow{2}{*}{$\begin{array}{c}\text { Q Rasional } \\
\text { (m3/det) }\end{array}$} & \multicolumn{2}{|c|}{ Penyimpangan } & \multirow{3}{*}{ Konversi } & \multirow{3}{*}{$\begin{array}{c}\text { Faktor } \\
\text { Koreksi } \\
(\mathrm{C})\end{array}$} \\
\hline & & & (m3/det) & $\%$ & & \\
\hline & a & $\mathrm{b}$ & $c=b-a$ & $d=c / a \times 100$ & & \\
\hline 2 & 419.02 & 214.31 & -204.71 & -48.85 & 1.96 & \multirow{6}{*}{2.04} \\
\hline 5 & 542.94 & 270.04 & -272.90 & -50.26 & 2.01 & \\
\hline 10 & 624.98 & 306.94 & -318.04 & -50.89 & 2.04 & \\
\hline 25 & 703.68 & 342.34 & -361.34 & -51.35 & 2.06 & \\
\hline 50 & 805.55 & 388.134 & -417.42 & -51.82 & 2.08 & \\
\hline 100 & 881.89 & 422.47 & -459.42 & -52.09 & 2.09 & \\
\hline
\end{tabular}

Sumber : Hasil Perhitungan

Tabel 16. Penyimpangan (\%) debit banjir rencana metode Der Weduwen terhadap debit banjir rencana data debit

\begin{tabular}{|c|c|c|c|c|c|c|}
\hline \multirow{3}{*}{$\begin{array}{c}\text { Kala } \\
\text { Ulang }\end{array}$} & \multirow{3}{*}{$\begin{array}{c}\mathrm{Q} \\
\text { Terukur } \\
\text { (m3/det) } \\
\mathrm{a}\end{array}$} & \multirow{3}{*}{$\begin{array}{c}\text { Q Der Weduwen } \\
\text { (m3/det) } \\
\text { b }\end{array}$} & \multicolumn{2}{|c|}{ Penyimpangan } & \multirow{3}{*}{ Konversi } & \multirow{3}{*}{$\begin{array}{l}\text { Faktor } \\
\text { Koreksi } \\
\text { (C) }\end{array}$} \\
\hline & & & (m3/det) & $\%$ & & \\
\hline & & & $c=b-a$ & $d=c / a \times 100$ & & \\
\hline 2 & 419.02 & 579.43 & 160.41 & 38.28 & 0.72 & \multirow{6}{*}{0.73} \\
\hline 5 & 542.94 & 740.97 & 198.03 & 36.47 & 0.73 & \\
\hline 10 & 624.98 & 850.24 & 225.26 & 36.04 & 0.74 & \\
\hline 25 & 703.68 & 956.74 & 253.06 & 35.96 & 0.74 & \\
\hline 50 & 805.55 & 1096.92 & 291.37 & 36.17 & 0.73 & \\
\hline 100 & 881.89 & 1203.73 & 321.84 & 36.50 & 0.73 & \\
\hline
\end{tabular}

Sumber : Hasil Perhitungan

Tabel 17. Penyimpangan (\%) debit banjir rencana metode Haspers terhadap debit banjir rencana data debit

\begin{tabular}{|c|c|c|c|c|c|c|}
\hline \multirow{3}{*}{$\begin{array}{l}\text { Kala } \\
\text { Ulang }\end{array}$} & \multirow{3}{*}{$\begin{array}{c}\text { Q } \\
\text { Terukur } \\
\text { (m3/det) } \\
a\end{array}$} & \multirow{3}{*}{$\begin{array}{c}\text { Q Haspers } \\
\text { (m3/det) } \\
\text { b }\end{array}$} & \multicolumn{2}{|c|}{ Penyimpangan } & \multirow{3}{*}{ Konversi } & \multirow{3}{*}{$\begin{array}{c}\text { Faktor } \\
\text { Koreksi } \\
(\mathrm{C})\end{array}$} \\
\hline & & & (m3/det) & $\%$ & & \\
\hline & & & $c=b-a$ & $\mathrm{~d}=\mathrm{c} / \mathrm{a} \times 100$ & & \\
\hline 2 & 419.02 & 1026.53 & 607.51 & 144.98 & 0.41 & \multirow{6}{*}{0.39} \\
\hline 5 & 542.94 & 1435.32 & 892.38 & 164.36 & 0.38 & \\
\hline 10 & 624.98 & 1631.43 & 1006.45 & 161.04 & 0.38 & \\
\hline 25 & 703.68 & 1819.55 & 1115.87 & 158.58 & 0.39 & \\
\hline 50 & 805.55 & 2063.05 & 1257.50 & 156.10 & 0.39 & \\
\hline 100 & 881.89 & 2245.52 & 1363.63 & 154.63 & 0.39 & \\
\hline
\end{tabular}

Sumber : Hasil Perhitungan

Hasil perhitungan debit banjir rencana mengunakan metode Rasional, metode Der 
Weduwen, metode Haspers serta debit banjir rencana dari data debit terukur dapat dilihat pada tabel 18.

Tabel 18. Debit Banjir Rencana Menggunakan Data Curah Hujan dan Data Debit

\begin{tabular}{ccccc}
\hline \multirow{2}{*}{$\begin{array}{c}\text { Kala Ulang } \\
\text { (Tahun) }\end{array}$} & \multicolumn{4}{c}{ Debit Banjir Rencana $(\mathrm{m} 3 / \mathrm{det})$} \\
\cline { 2 - 5 } & Rasional & Der Weduwen & Haspers & Debit Terukur \\
\hline 2 & 214.31 & 579.43 & 1026.53 & 419.02 \\
5 & 270.04 & 740.97 & 1435.32 & 542.94 \\
10 & 306.94 & 850.24 & 1631.43 & 624.98 \\
25 & 342.34 & 956.74 & 1819.55 & 703.68 \\
50 & 388.13 & 1096.92 & 2063.05 & 805.55 \\
100 & 422.47 & 1203.73 & 2245.52 & 881.89 \\
\hline
\end{tabular}

Sumber : Hasil Perhitungan

\section{KESIMPULAN}

Dari hasil penelitian diperoleh beberapa kesimpulan, antara lain:

1. Dari hasil perhitungan debit banjir rencana berdasarkan data curah hujan menggunakan metode Rasional, metode Der Weduwen dan Metode Haspers serta perhitungan debit banjir rencana berdasarkan data debit didapat bahwa nilai debit banjir rencana yang mendekati nilai debit banjir rencana data debit terukur dalah metode Der Weduwen.

2. Penyimpangan terkecil terjadi terhadap metode Der Weduwen yaitu sebesar $38.28 \%$ untuk kala ulang 2 tahun, 36.47\% untuk kala ulang 5 tahun, $36.04 \%$ untuk kala ulang 10 tahun, 35.96\% untuk kala ulang 20 tahun, $36.17 \%$ untuk kala ulang 50 tahun dan $36.50 \%$ untuk kala ulang 100 tahun. Oleh karena itu, metode Der Weduwen dapat digunakan sebagai acuan untuk perhitungan debit banjir rencana penanggulangan bencana banjir di Sungai Negara apabila data debit terukur tidak diperoleh.

\section{DAFTAR PUSTAKA}

[1] Harto, Sri.1993. Analisis Hidrologi. PT. Gramedia. Jakarta.

[2] Loebis, Joesron. 1992. Banjir Rencana Untuk Bangunan Air. Departemen Pekerjaan Umum. Jakarta.

[3] Marcelia, 2014, Ketelitian Metode Empiris Untuk Menghitung Debit Banjir Rancangan di Das Bangga. Jurnal Infrastruktur volume 4. Palu.

[4] Sharon dkk, 2014, Analisis Debit Banjir Sungai Tondano Menggunakan Metode HSS Gama I dan HSS Limantara. Jurnal Sipil Statik Volume 4 No. 1. Manado.
[5] Soewarno. 1995. Hidrologi Untuk Aplikasi Metode Statistik Untuk Analisa Data Jidil 1. NOVA. Bandung.

[6] Soewarno, 1991. Hidrologi Pengukuran dan Pengolahan Data Aliran Sungai. PT Nova, Bandung.

[7] Sosrodarsono, Suyono dan Kensaku Takeda. 1977. Hidrologi Untuk Pengairan. PT Pradyna Paramita. Jakarta.

[8] Subarkah Imam, Ir. 1978. Hidrologi Untuk Perencanaan Bangunan Air. Idea Dharma, Bandung

[9] Triadmodjo, Bambang. 2008. Hidrologi Terapan. Beta Offset. Yogyakarta

\section{UCAPAN TERIMA KASIH}

Penulis mengucapkan terima kasih kepada Bapak M. Azhari Noor, ST, M.Eng dosen Program Studi Teknik Sipil Fakultas Teknik Universitas Lambung Mangkurat atas masukan dan bantuannya dalam penyelesaian jurnal ini 